\title{
ERROR ANALYSIS OF USING SIMPLE PRESENT TENSE ON STUDENTS' DESCRIPTIVE TEXT WRITING
}

\author{
Susiana Pancawati ${ }^{1}$, Nina Dwiastuty ${ }^{2}$ \\ ${ }^{1,2}$ Program of English Education, Faculty of Languages and Arts, Universitas Indraprasta PGRI \\ Jalan Nangka No. 58C, Jagakarsa, Tanjung Barat, Jakarta Selatan 12530, Indonesia
}

Corresponding Author(S): ninadwiastuty@yahoo.com

\begin{abstract}
:
The purpose of the research is to find out the types of error which made by the ninth graders in writing descriptive text using simple present tense at SMPIT Nurul Ihsan. The number of the students is 27 students. This research uses qualitative descriptive as the approach. The researcher directly did the survey and conducted a written test to the students write English descriptive text. The result of the study shows that there are 77 errors from all students' compositions. The most error made is misformation with the percentage $49,35 \%$. Followed misordering with the percentage $20,78 \%$, then addition with the percentage $18,18 \%$, and the least error made is omission with the percentage is 11,69\%. Most students made wrong sentence in misformation category. The cause of that is the interference from mother language or L1. It makes them influenced the way they think about the language they are learning. When they compose a text in English, they follow the rule of L2. Consequently, they should be guided more so that they could understand about simple present tense.
\end{abstract}

Keywords: Error, Analysis, Descriptive text

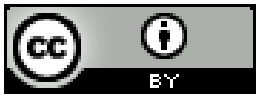

Creative Commons Attribution 4.0 International License

\section{INTRODUCTION}

To communicate is one of the humans' interaction forms in sharing information. Humans have language to communicate each other. They can express feelings, thoughts, ideas, and hopes. The form of communication can be spoken language, written language, and gesture or body language, and so forth. There are so many various languages in all over the world. Every region or country uses different language. Indonesia which consists of different races, tribes, and cultures from all over the regions has various languages. There are sundanese which is used in West Java, Javanese used in Central Java and East Java, Bataknese used in Medan, and so on. Thus, Indonesia uses Indonesian Language as national language to unite its people in their daily communication.

On the other side, Indonesian language is not an international language that is used by all people from all countries. The international languge is English. So, English can be called as lingua franca which is used by people from all the countries to communicate each other. Entering the free trade era, many foreigners come to Indonesia for survival. In Jakarta, 
there are many foreigners that we can see, they are: in the companies, English courses and other workplaces. Remembering that, we as Indonesian may not loose with them in works (Nurjanah, Anggoro and Dwiastuty, 2017:310). Consequently, this condition makes English language to be compulsory subject to learn in Indonesia. It starts from elementary school even from kindergarten. The students are acquainted to English from the beginning level. English is also inserted in the national final exam both in junior high school and senior high school at the end of the academic year or the last period the students end their education in those grades.

In learning English, the learner does not only learn about how to speak well, but also to listen, to read, and to write appropriately because those skills are the domain students' competency in learning English. Indonesia government applies 2013 curriculum that emphasizes on attitude, knowledge, and skills in the education levels. Therefore, nowadays the quality of the learner is not only seen by the knowledge but also the attitude or the characters and the skills. Especially in learning English, the learners are not only required to master the theory of language, the formula of tenses, grammar, and vocabulary but also they are hopefully able to use the language both spoken and written. In learning English, there are four skills that have to be mastered. They are speaking, listening, reading, and writing. Speaking skill is a skill to speak or to produce words orally, listening skill is a skill to accept and to comprehend information through audio sense, reading skill is a skill to read and to comprehend information in the form of text, and writing skill is a skill to write message, information, or text to be read by others.

Writing is an important point in the learning English series process. Writing is a skill that is not easy to do. The learner has to think about the ideas and the details to connect them correctly. Langan (2009:37) says "Writing is a process of discovery that involves a series of steps, and those steps are very often zigzag journey". On the other hand, writing is a long process. There are many steps in the writing process because writing is a skill so that someone should practice it for a better writing. It needs the skill to compose words and sentences into a good composition.

One of the basic lessons in learning English at the early time is simple present time which talks about general truths, facts, and habits. This tense also appears as language feature in descriptive text. In writing descriptive text, the students use this tense to describe people, animals, things, and places combined with some adjectives. Making errors and mistakes is still an inhibiting factor in learning foreign language. Errors and mistakes show that students have not mastered the rules of the language they are learning. To cope this problem, some linguists use error analysis as the strategy. Brown (2000:166) says that "Error is the study of students' errors which can be observed, analyzed, and classified to reveal something of the system operating within the learners". By doing error analysis, it would help teachers because it will reveal some problems faced by the students.

Error analysis is a methodology for investigating learners' competence in acquiring a second language acquisition of a foreign language. It describes learners' interlanguage and can be used to identify the possible error made by students. Types of errors are dealing with the surface characteristic error that is often called surface strategy taxonomy. The researcher uses the surface strategy taxonomy because by analyzing the types of error based on the surface strategy taxonomy, some advantages can be obtained. There are four 
types of errors as stated by Dulay, Burt, and Krashen (1982), they are: omission, addition, misformation, and misordering.

There are many errors and mistakes in learning English tenses but making errors and mistakes is normal and unavoidable. Norrish (1983:3) says that "Most of language learners only acquire an active knowledge of the language if they have the chance to listen to a great deal of language and to make numerous mistakes while expressing themselves in it". Thus, it is natural for the students as human being to make error, even many native speakers produce many mistakes in speaking, and they would be unaware of the way they speak unless they heard recording of themselves. Wishon and Burks in Arifin, et. al. (2014:84) affirm that "Descriptive writing reproduces the way of looking, smelling, tasting, feeling, hearing a particular thing. Descriptive text uses senses to show the picture in words of the object". Moreover, Langan (2009:92) further asserts descriptive text as follows:

"When you describe something or someone, you give your readers a picture in words. To make this "word picture" as vivid and real as possible, you must observe and record specific details that appeal to your readers' senses (sight, hearing, taste, smell, and touch). More than any other type of writing, a descriptive paragraph needs sharp, colorful details".

Callaghan and Rothery (1998:138) add "Descriptive text creates a clear and vivid impression of person, place or thing". When a writer writes a descriptive text, he/she should use a concrete and detail words, so the readers understand well what the writer is actually telling about. Description is a written English text in which the writer describes an object. In this text, the object can be a concrete or abstract object. It can be a person, or an animal, or a tree, or a house, or camping. It can be about any topic. It is admitted that writing is viewed as the most complex and hardest language skill among the others. The students need to think everything at once. They should produce words, sentences, paragraphs, and extending compositions at the same time. That is why some experts said that writing is not an automatic process and it is the hardest skill that should be mastered by the students. The researcher emphasizes this research in students' competence in writing ability especially in writing descriptive text that is learnt in the ninth-grade semester 1 .

\section{METHOD}

This research uses qualitative approach. Denzin and Lincoln in Cresswell (2014) argue that this kind of research makes the researcher learns all the things around, tries to make interpretation of phenomena in meaning view from the people. In addition, the researcher turns the world into a series of representation that covers notes, interviews, recordings of dialog, conversations, photos and personal notes. In this case, qualitative research takes naturalistic interpretation.

The researcher used notes as the data to be analyzed, that is, descriptive text written by the ninth graders of SMPIT Nurul Ihsan. All the compositions were then collected to be analyzed to identify errors made by students. The research was carried out in November 2019 of the first semester of the academic year 2019/2020. The research technique used was descriptive analysis. Descriptive analysis writing here was used to clarify, to explain, and to analyze errors made by the students, related to the errors in omission, addition, 
misformation, and misordering in descriptive text using simple present tense. The researcher used an assignment as the instrument of the research to measure the students' writing skill.

The researcher asked the students to make a descriptive text by using simple present tense. They wrote descriptive text to describe animal. The researcher asked the students to write the descriptive text based on the material which had been given before. Besides giving the assignment, the researcher used other instrument in the form of a table of error classification to ease the researcher in analyzing the data. All the incorrect sentences of using simple present tense in the students' descriptive text are included in the table and constructed the right form, then categorized which types of errors they are in.

\section{RESULTS AND DISCUSSION}

The data is obtained then it is categorized and reconstructed to have the right form of wrong sentence. After analyzing the data, then the researcher calculates the errors based on the types of errors found in students' writing. The error recapitulation is as follows:

Table 1 Error Calculation

\begin{tabular}{|c|c|c|c|c|c|}
\hline $\begin{array}{l}\text { Student's } \\
\text { Number }\end{array}$ & $\begin{array}{c}\text { Error of } \\
\text { Omission }\end{array}$ & $\begin{array}{c}\text { Error of } \\
\text { Addition }\end{array}$ & Misformation & Misordering & Total \\
\hline 1 & - & - & 2 & - & 2 \\
\hline 2 & - & - & 2 & - & 2 \\
\hline 3 & - & - & 2 & - & 2 \\
\hline 4 & - & - & 2 & - & 2 \\
\hline 5 & 1 & - & 2 & 1 & 4 \\
\hline 6 & - & - & 1 & 1 & 2 \\
\hline 7 & 2 & - & 1 & 2 & 5 \\
\hline 8 & - & 1 & 3 & 2 & 6 \\
\hline 9 & 1 & - & 1 & - & 2 \\
\hline 10 & - & - & 1 & 1 & 2 \\
\hline 11 & - & - & 1 & 1 & 2 \\
\hline 12 & 1 & 1 & - & - & 2 \\
\hline 13 & 1 & 1 & 3 & 2 & 7 \\
\hline 14 & 1 & - & 1 & - & 2 \\
\hline 15 & - & 4 & - & - & 4 \\
\hline 16 & - & 3 & - & - & 3 \\
\hline 17 & - & - & - & 2 & 2 \\
\hline 18 & - & - & 3 & - & 3 \\
\hline 19 & - & - & 2 & - & 2 \\
\hline 20 & 2 & 1 & - & - & 3 \\
\hline 21 & - & - & 2 & - & 2 \\
\hline 22 & - & 1 & 2 & 1 & 3 \\
\hline 23 & - & 1 & 1 & - & 2 \\
\hline 24 & - & - & 1 & 1 & 2 \\
\hline 25 & - & - & 2 & - & 2 \\
\hline 26 & - & - & 1 & 1 & 2 \\
\hline 27 & - & 1 & 3 & 1 & 5 \\
\hline Total & 9 & 14 & 38 & 16 & 77 \\
\hline
\end{tabular}

By calculating the frequency of each type of errors, the researcher could identify the kinds of students' errors of using simple present tense in writing descriptive text. The calculation is follows:
1. Omission
$: \frac{9 \times 100 \%}{77}=11,69 \%$
2. Addition
$: \frac{14 \times 100 \%}{77}=18,18 \%$
3. Misformation
$: \frac{38 \times 100 \%}{77}=49,35 \%$
4. Misordering
$: \frac{16 \times 100 \%}{77}=20,78 \%$ 


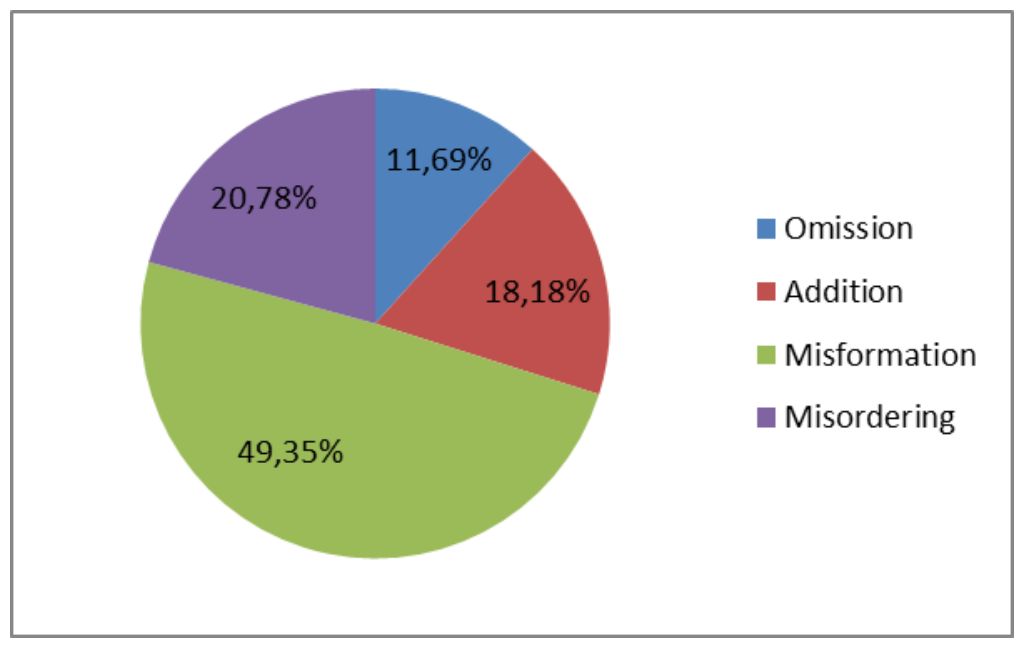

Figure 1 Error Percentage

While the following is the number of students who made each type of error:

Table 2 Types of Error Made by Students

\begin{tabular}{cll}
\hline No. & Type of Error & Number of Students \\
\hline 1. & Omission & 7 of 27 students \\
2. & Addition & 9 of students \\
3. & Misformation & 22 of 27 students \\
4. & Misordering & 12 of 27 students \\
\hline
\end{tabular}

From the error calculation table, the total of errors made by the ninth graders is 77 errors in writing descriptive text using simple present tense. There are 9 omission errors, 14 addition errors, 38 misformation errors, and 16 misordering errors. Misformation error is the most error the students made, and omission error is the least error the students made. The error range from dominant errors can be explained below:

1. Omission

Some students missed to be in nominal sentence when they state their opinions about their animals. Most of the sentences are like this: "It very active", "Michalle 19 centimeters long", "Its tail long". Those sentences need to be "is". This error is caused by interlingual transfer. This interference comes from L1 (Indonesian). The learners are still not familiar with the grammar or language structure of L2 (English).

2. Addition

Some students added extra words which actually are not needed in the sentences. As they are found in some verbal forms: "It is plays", "It is has tail", "He is has feather", "It is likes carrot". This error is caused by intralingual transfer. It means that error comes from the target language which being learned by the students. It is usually happened to beginner level of learners and it shows the progress in learning language.

3. Misformation

This error is the most error type that the students made. Here are the samples of that type of error: "I has animal", "Nibaw eating carrot", "Melo have shell" "It don't play". All the verbs in those sentences have wrong verb form, they are: has, eating, have, and don't play. Many students used the wrong word and they are confused about verb agreement between subject and verb. Especially have/has, verb+ing/verb + s/es, 
don't/doesn't. They need more comprehension about that and one who tells about the misunderstanding in using simple present tense.

4. Misordering

There are many sentences which have wrong phrase especially of the noun phrase. The examples are: "Bunny has eyeballs black", "Nibaw has teeth sharp". The students are failed to arrange the noun phrase. They misplaced noun and modifier. Noun is always at the ending, and it is preceded by modifier. This error is caused by the interference from L1 or interlingual transfer. Again, the students are not familiar with the structure of L2.

\section{CONCLUSION}

Based on the findings, there are many errors of using simple present tense in descriptive text writing in the ninth grade at SMPIT Nurul Ihsan. Many students made various types of errors, such as omission, addition, misformation, and misordering. In omission error, the students missed to be in nominal sentences. In addition error, the students added to be in verbal sentences. In misformation error, the students used the wrong verb form just like playing/plays, eating/eats, don't/doesn't. They need to learn more about subject and verb agreement in simple present tense. In misordering, most sentences have misordered the noun phrase. The most dominant type of error that the students made in their descriptive text writing is misformation with the percentage $49,35 \%$, next is misordering with the $20 \%$, then addition $18,18 \%$, and the last omission with the percentage $11,69 \%$.

The most dominant factor of the error is about the context of learning which there is no one who teaches or guides the learners in their learning process. Therefore, the students themselves interpret what they have learnt. From this case, it can be said that the students need more guidance in learning English. The most second factor is interlingual transfer, as the proofs are the sentences in omission and misordering sentences. The interference comes from the structure of L1 and the students are not familiar with the structure of L2. They missed some words to construct sentences in L2. In contrast with L1 (Indonesian), Indonesian sentences do not need to be or auxiliary to state an utterance. In short, the students' mastery about simple present tense that is used in writing descriptive text should be improved because they have not understood about the structure differences between Indonesian and English. Many English verb forms, well-ordered sentence, and verb agreement that must be understood by the students.

\section{REFERENCE}

Arifin, A., Retmono, \& Warsono. (2014). Mistakes within the descriptive texts produced by undergraduate students. English Education Journal, (2).

Brown, H. D. (2000). Principles of Language Learning and Teaching. Fourth Edition. New Jersey: Prentice Hall.

Callaghan, M., \& Rothery J. (1998). Teaching Factual Writing. Sydney: Metropolitan East Disadvantaged School Program.

Cresswell, J. W. (2014). Penelitian Kualitatif: Memilih Diantara Lima Pendekatan. Edisi Ke-3. Terjemahan Ahmad Lintang Lazuardi. Yogyakarta: Pustaka Pelajar.

Dulay, H., Burt, M., \& Krashen, S. (1998). Language Two. New York: Oxford University Press.

Langan, J. (2009). Exploring Writing Sentences and Paragraph. Newyork: McGraw-Hill. 
Norrish, J. (1983). Language Learners and Their Errors. London and Basingstoke: Macmillan.

Nurjanah, Anggoro, D., Dwiastuty, N. (2017). Error analysis of the use of question words in English sentences. Scope: Journal of English Language Teaching, 1(3),309317. 